\title{
CLINICAL AND PARACLINICAL CONSIDERATIONS REGARDING ACUTE CHOLECYSTITIS
}

Bonțea Mihaela Gabriela, Voiță Gh. Florin, Mekeres Gabriel Mihai, Gavra Alexandra Simina, Maghiar Octavian Adrian

University of Oradea, Medicine and Pharmacy Faculty

Corresponding author: Voiță Gh. Florin, student; University of Oradea, Medicine and

Pharmacy Faculty

Email adress: voita_florin@yahoo.com

\section{Abstract}

The gallbladder represents a vast pathological subject, vastly disputed because of the many diseases and conditions that can develop. One of the diseases of the bladder is acute cholecystitis, a pathological entity that is induced by the acute inflammation of the gallbladder. It is of particular interest to the patients that present gallstones, with a prevalence of 10 to $25 \%$ of the total surgical interventions regarding the gallbladder diseases.

The objective of this article is to analyze the diagnosis and treatment of acute cholecystitis and highlight the importance of diet in this pathology.

The incriminating factor of acute cholecystitis is the biliary stasis, along with bacterial infections that also intervene and the possible ischemia of the bladder wall. In about 90 to $95 \%$ cases the biliary stasis is a follow up to the calculous obstruction of the cystic duct, context in which patients are diagnosed with acute lithiasic cholecystitis

Under antibiotic therapy clinical improvement occurs rarely, most often a stationary phase of acute cholecystitis settles in. The unfavorable evolutions refer to patients who develop complications. Bile peritonitis which may be generalized or localized, most often a localized peritonitis occurs, which will develop a plastron in a few days that acts as an armor, is even to touch and presents a dull percussion

Conclusions. Acute cholecystitis is a common disease in clinical practice, and most often it represents a surgical emergency. The quality of life of a patient that suffers from gallbladder diseases may be affected, as they must follow a certain diet.

Keywords: gallbladder, acute cholecystitis, dietary considerations. 


\section{General Revieus:}

\section{Rezumat}

Vezica biliară reprezintă un subiect patologic vast, foarte disputat din cauza numeroaselor afecțiuni care se pot dezvolta la acest nivel. Una dintre bolile vezicii urinare este colecistita acută, o entitate patologică care este indusă de inflamația acută a vezicii biliare. Este de interes deosebit în cazul pacienților care prezintă calculi biliari, cu o prevalență de 10 până la $25 \%$ din totalul intervențiilor chirurgicale asupra vezicii biliare.

Obiectivul acestui articol este de a analiza diagnosticul și tratamentul colecistitei acute și de a evidenția importanța dietei în această patologie.

Factorul incriminat pentru colecistita acută este staza biliară, împreună cu infecțiile bacteriene care intervin, de asemenea, și posibila ischemie a peretelui vezicii biliare. În aproximativ 90 până la 95\% dintre cazuri, staza biliară este o urmare a obstrucției prin calculi a canalului cistic, context în care pacienții sunt diagnosticați cu colecistită litiazică acută.

în contextul terapiei cu antibiotice, ameliorarea clinică apare rar, cel mai adesea se instalează o fază staționară de colecistită acută. Evoluțiile nefavorabile se referă la pacienții care dezvoltă complicații. Peritonita biliară care poate fi generalizată sau localizată, cel mai adesea fiind vorba de o peritonită localizată, cu dezvoltarea unui plastron, în câteva zile.

Concluzii. Colecistita acută este o boală frecventă în practica clinică și, cel mai adesea, reprezintă o urgență chirurgicală. Calitatea vieții unui pacient care suferă de boli ale vezicii biliare poate fi afectată, deoarece trebuie să urmeze o anumită dietă.

Cuvinte cheie: vezică biliară, colecistită acută, considerații dietetice. 
The gallbladder, also gall bladder or biliary vesicle, is a small organ and acts as a container that stores the bile during the interprandial period. It has an ovoid shape and is located inside the gallbladder fossa on the visceral face of the liver, having a sagittal direction, slightly oblique antero-posterior and from the right to the left. The length of the gallbladder is on average about 8 to 10 centimeters, and it has a capacity of 40 to 60 cubic centimeters $^{(1)}$.

The gallbladder represents a vast pathological subject, vastly disputed because of the many diseases and conditions that can develop. One of the diseases of the bladder is acute cholecystitis (figure 1), a pathological entity that is induced by the acute inflammation of the gallbladder. It is of particular interest to the patients that present gallstones, with a prevalence of 10 to $25 \%$ of the total surgical interventions regarding the gallbladder diseases, which affect a huge part of the world's population. It is generally associated with the obstruction of the bile duct, however it can develop at a small percentage of patients without the formation of gallstones and the obstruction of the duct ${ }^{(2)}$.

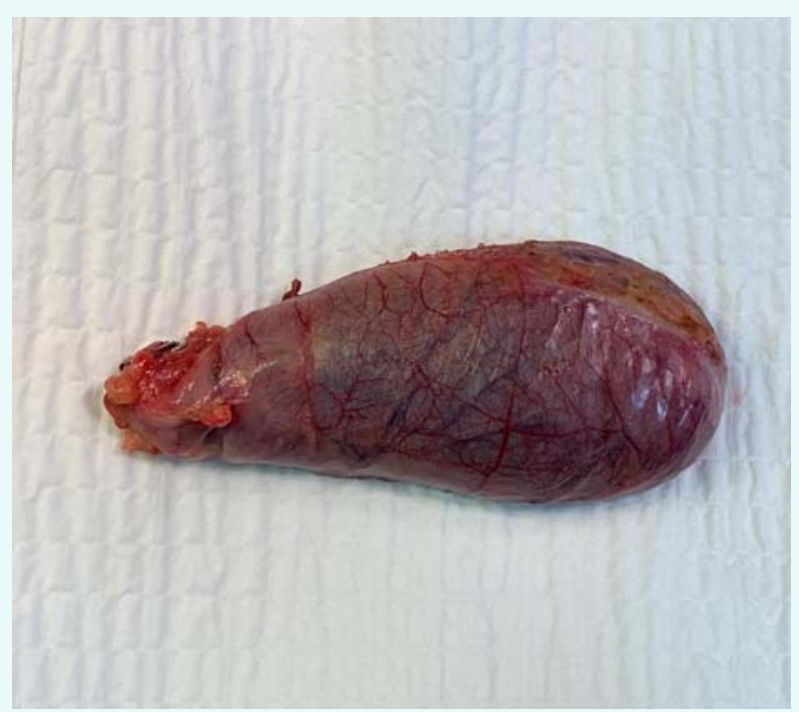

Figure 1. Gallbladder postcolecistectomy
The frequency and severity of this disease is much higher at patients over 60 , although it can occur at any age.

The objective of this article is to analyze the diagnosis and treatment of acute cholecystitis and highlight the importance of diet in this pathology.

The incriminating factor of acute cholecystitis is the biliary stasis, along with bacterial infections that also intervene and the possible ischemia of the bladder wall. In about $90 \%$ to $95 \%$ cases, the biliary stasis is a follow up to the calculous obstruction of the cystic duct, context in which patients are diagnosed with acute lithiasic cholecystitis ${ }^{(2)}$. If the obstruction has other causes, then the diagnosis changes to non-lithiasic acute cholecystitis. A high risk for acalculous cholecystitis to develop is associated with a series of medical problems, such as burns, trauma, or acute surgical interventions ${ }^{(3)}$.

The onset of this disease manifests itself by epigastric pain with an irradiation tendency into the right hypochondriac region and intensity that gradually gets worse over a period of 48 hours. Nausea and vomiting occur frequently, especially with patients that also present pancreatic conditions, fever that doesn't exceed $38^{\circ} \mathrm{C}$ along with chills, this might hint at certain complications such as suppurative perforation or angiocholitis ${ }^{(4)}$.

The painful contraction of the abdominal muscles in the right hypochondriac region, is highlighted during the physical examination, where the Murphy maneuver is used. In around $25 \%$ to $30 \%$ of the cases, patients present a distended gallbladder, distinguished by palpation, also at one in four patients jaundice occurs, having a moderate intensity. By providing a suitable treatment, acute cholecystitis is healed in $65 \%$ to $75 \%$ of cases, signs of improvement being visible 


\section{INTERNAL}

\section{General Reviews}

after the first day of treatment, and the healing process is completed in a week. The cases that responded well to the treatment still remain open to the risk of relapsing with a chance of $60 \%$ in the following 6 years after the treatment ${ }^{(6)}$. In order to confirm the diagnosis certain examinations and imaging tests are required. Laboratory tests can reveal mild leukocytosis, slight increase in the serum bilirubin level, and moderate increase of alkaline phosphatase. Ultrasound is used to show the presence of gallstones and occasionally a phlegmonous mass around the gallbladder. Radioisotope scintigraphy may identify the cystic duct obstruction ${ }^{(4)}$.

Surgical treatment is needed in all the cases where acute cholecystitis lithiasis and its symptoms do not resolve within 24 hours.

Hygienic and dietary treatment is of major importance for this condition. Bed rest is compulsory as well as the use of an ice pack. The patient's diet will consist exclusively of water, and small quantities of tea. After 3 to 4 days, depending on how the patient is recuperating, they may begin with a diet based on water and glucose, subsequently vegetable soup, rice, semolina and biscuits. Antibiotherapy is another important step in combating the infection, as well as electrolyte rebalance if necessary. The pain will be treated with pethidine, papaverine, belladonna based preparations. The administration of opioids will be avoided in order not to cause a spasm of the sphincter of Oddi. The optimal time for surgery depends on how stable the patient's condition is, but the intervention should happen as soon as possible ${ }^{(4,5)}$.

Under antibiotic therapy clinical improvement occurs rarely, most often a stationary phase of acute cholecystitis settles in. The unfavorable evolutions refer to patients who develop complications. Bile peritonitis which may be generalized or localized, most often a localized peritonitis occurs, which will develop a plastron in a few days that acts as an armor, is even to touch and presents a dull percussion ${ }^{(6)}$.

Acute cholecystitis under drug therapy may develop into slow resorption, incomplete or form an abscess, when the overall condition worsens, pain increases, septic fever occurs, the leukocytosis increases, and local plastron softening occurs. Another complication is angiocholitis, which can have severe forms as ictero-uremigene angiocolithis.

Surgical intervention is required in case of diagnosis of gallbladder stones, lithiasis or alithiasic acute cholecystitis (figure 2).

Patients that will undergo surgery wonder how the cholecystectomy will affect the quality of their lives, and what kind of diet they must follow. To this question, doctors try to give an answer based on the observations they have made on how cholecystectomies evolve in other patients, but unfortunately the evolution varies from patient to patient, thus giving a singular universal answer is quite difficult. 


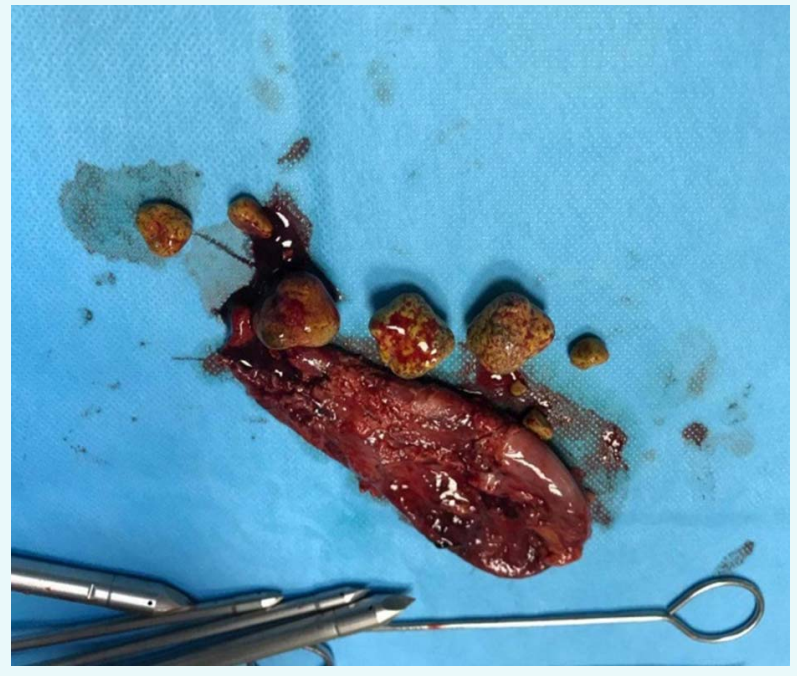

Figure 2. Gallbladder calculi

According to most doctors a cholecystectomy affects a patient's life to some extent, a disadvantage representing weight gain. Patients who have undergone this procedure need to follow a strict hypocaloric diet to keep their weight on check. The strict diet will be kept at least six months after the cholecystectomy. If the patient has fatty liver disease or other chronic liver disease, the regime will be held for a longer period ${ }^{(8)}$.

\section{Conclusions}

Acute cholecystitis is a common disease in clinical practice, and most often it represents a surgical emergency.
Cholecystectomy is the surgical removal of the gallbladder, it represent a common treatment of symptomatic gallstones and other gallbladder conditions.

The quality of life of a patient that suffers from gallbladder diseases may be affected, as they must follow a certain diet.

\section{References:}

1. Grey's Atlas of Anatomy 2007 -A.Wayne Volg, Adam W. M. Mitchell;

2. Anatomia omului, Volumul 2 Splahnologia -Victor Papilian, 2006, editia a XII-a Editura ALL;

3. Medicina interna pentru cadre medii - Corneliu Borundel 2009 Editura ALL;

4. Harrison Manual de Medicina - Dan L. Longo 2014 Editura ALL MEDICALL;

5. http://anatomie.romedic.ro/cai-biliare-vezica-biliara;

6. http://anatomie.romedic.ro/patologia-cailor-biliaresindroame-biliare:

7. http://www.gabimatei.ro;

8. http://www.ziaruldeiasi.ro/ghidul-pentrusanatate/operatia-de-extirpare-a-bilei-nerespectarearegimului-alimentar-dupa-colecistectomie-poate-favorizaaparitia-unor-complicatii;

9. Järvinen, Heikki J., and Junno Hästbacka. "Early cholecystectomy for acute cholecystitis: a prospective randomized study." Annals of surgery 191.4 (1980): 501;

10. Hirota, Masahiko, et al. "Diagnostic criteria and severity assessment of acute cholecystitis: Tokyo Guidelines." Journal of hepato-biliary-pancreatic surgery 14.1 (2007): 78-82;

11. Barie, Philip S., and Soumitra R. Eachempati. "Acute acalculous cholecystitis." Acute Cholecystitis. Springer International Publishing, 2015. 187-196. 